SHORT COMMUNICATION

\title{
New records of three Neotropical arboreal ant species of Camponotus, subgenus Dendromyrmex (Hymenoptera: Formicidae) for the southern Amazon, including biological information
}

\author{
Ricardo Eduardo VICENTE ${ }^{1,2, *}$, Diego FERREIRA-SILVA, Mendelson GUERREIRO DE LIMA ${ }^{1}$ \\ 1 Universidade do Estado de Mato Grosso, Faculdade de Ciências Biológicas e Agrárias, Departamento de Ciências Biológicas, Campus II, Alta Floresta, MT, Brazil \\ 2 Universidade Federal de Mato Grosso, Núcleo de Estudos da Biodiversidade da Amazônia Mato-grossense, Sinop, MT, Brazil \\ * Corresponding author: ricardomyrmex@gmail.com
}

\section{ABSTRACT}

Camponotus (Formicinae) is the most specious and abundant genus of the family Formicidae. The genus is represented by ants that both forage and nest in the most diverse terrestrial and arboreal environments. Among the arboreal species of Camponotus are those of the subgenus Dendromyrmex. We recorded, for the first time, evidence of Camponotus chartifex (Smith, 1860) in the state of Mato Grosso, Brazil, and expanded the distributions of Camponotus nidulans (Smith, 1860) and Camponotus apicalis (Mann, 1916). We include information on the biology of the species and a discussion on the sampling of arboreal and winged ants.

KEYWORDS: distribution; Formicinae; Camponotus chartifex; Camponotus nidulans; Camponotus apicalis; winged ants

\section{Novos registros de três espécies neotropicais de formigas arborícolas de Camponotus, subgênero Dendromyrmex (Hymenoptera: Formicidae) para a Amazônia meridional, incluindo dados de história natural}

\section{RESUMO}

Camponotus é um dos gêneros mais especiosos e abundantes da subfamília Formicidae. O gênero é representado por formigas que se alimentam e nidificam nos mais diversos habitats de ambientes terrestres e arbóreos. Entre as espécies arborícolas de Camponotus, estão as do subgênero Dendromyrmex. Registramos, pela primeira vez, Camponotus chartifex (Smith, 1860) para o estado de Mato Grosso, Brasil, e expandimos a distribuição de Camponotus nidulans (Smith, 1860) e Camponotus apicalis (Mann, 1916), incluindo informaçóes biológicas sobre as espécies e uma discussão sobre a amostragem de formigas arborícolas e aladas.

PALAVRAS-CHAVE: distribuição; Formicinae; Camponotus chartifex; Camponotus nidulans; Camponotus apicalis; formigas aladas

The Formicinae subfamily comprises about 3,055 species and 804 subspecies in 51 genera around the world, of which 14 genera occur in the Neotropical region (Baccaro et al. 2015; AntMaps 2018; AntWeb 2018). Among the genera of the subfamily Formicinae, one of the most speciose and abundant is the genus Camponotus Mayr, 1861, with about 1,023 described species, of wich about 470 occur in the Neotropics (Ryder-Wilkie et al. 2010; Santos-Silva et al. 2016; AntWeb 2018). Camponotus is also well represented in the Amazon region, comprising $1.99 \%$ to $9.33 \%$ of sampled ant fauna in the biome (Vicente et al. 2016). The genus is represented by ants that forage on the ground and in litter microhabitats, and arboreal ants that nest on vegetation, rocks, and organic matter.
In addition, in some cases, arboreal ants of this genus prefer the soft wood of trees for the construction and maintenance of their nests (Fernandes et al. 2014; Suguituru et al. 2015).

The arboreal ant species of the genus Dendromyrmex Emery were reallocated as a subgenus of Camponotus, because they do not have autapomorphies (Fernández 2002). The species in this group are characterized by colonies with exclusively monomorphic workers (which are di- or polymorphic in other subgenera of Camponotus), and dorsal and lateral angular propodeum and dorsum with transverse striation (Fernández 2002). Thus the morphology of Dendromyrmex falls within the general morphology of Camponotus, and Dendromyrmex is 
likely a monophyletic group if the monomorphy is a derived trait in a typically dimorphic genus. Very little is known about the biology and natural history of Dendromyrmex, and there are several gaps in the distribution of species.

Workers of three species of Camponotus subgenus Dendromyrmex were collected in four municipalities in the state of Mato Grosso, Brazil (Figure 1). We used the taxonomic key of Fernández (2002) to identify the species as Camponotus apicalis (Mann, 1916), Camponotus chartifex (Smith, 1860), and Camponotus nidulans (Smith, 1860). The identification of the specimens was confirmed by a specialist (Dr. Rodrigo Feitosa), the specimens were deposited in the Entomological Collection Padre Jesus Santiago Moure of the Department of Zoology of Universidade Federal do Paraná (DZUP) and the Entomological Collection of Museu Paraense Emilio Goeldi (MPEG). The distribution of the species was assessed on AntMaps (Guénard et al. 2017), and the literature on behavior of the species was reviewed.

Workers of $C$. apicalis were sampled in Estação Ecológica

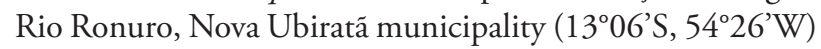
in November 2016 using the beating-tray method (an adapted entomological umbrella) in the vegetation (Figure 2A) (collection vouchers DZUP-REV16001BT, MPEG. HHY-03036215). Camponotus chartifex were sampled directly in their nest in Parque Nacional do Juruena, Apiacás municipality $\left(09^{\circ} 20^{\prime} \mathrm{S}, 57^{\circ} 53^{\prime} \mathrm{W}\right)$, in July 2011 (Figure 2B) (collection vouchers DZUP-REV11007CM). We measured the distance of the nest to the ground, and worker behavior was observed and photographed. Workers and one male of C. nidulans were collected in a sampling module of Program PPBio (https://ppbio.inpa.gov.br/) in the municipality of Claudia $\left(11^{\circ} 35^{\prime} \mathrm{S}, 55^{\circ} 15^{\prime} \mathrm{W}\right)$ using the beating-tray method in vegetation during the day (Figure 2C) (collection vouchers DZUP-REV09004BT, MPEG.HHY-03036213). Workers of $C$. nidulans were also collected in 2010 and 2011 using the beating-tray method in São Nicolau Farm, Cotriguaçu municipality (0948'S; 58¹5'W) (Dáttilo et al. 2013) (collection vouchers DZUP-REV09006BT).

Camponotus apicalis has a known distribution from the Lesser Antilles to Bolivia (Kempf 1972; Fernández 2002). In Brazil, it had previously been recorded in the northern and northeastern regions, in the states of Amazonas, Pará, Rondônia, Bahia, and also in Mato Grosso (Kempf 1972; Fernández 2002). We collected C. apicalis at night when active in the understory vegetation of a river margin. The sampling site was surveyed twice (day and night) in November 2016 and twice (day and night) in February 2017. During these surveys, no nest was observed, and no workers were collected. This is a sign that during the night $C$. apicalis were active far from the nest, reinforcing the supposition that ants in this group have nocturnal habits. Males of the subgenus Dendromyrmex were collected in the same square meter of vegetation where
C. apicalis workers were sampled. Males of $C$. apicalis were not described so far, so that future taxonomic revisions should look into male chracterization and differentiation in these taxons.

This is the first record of $C$. chartifex for the state of Mato Grosso. The species occurs in the Neotropical region
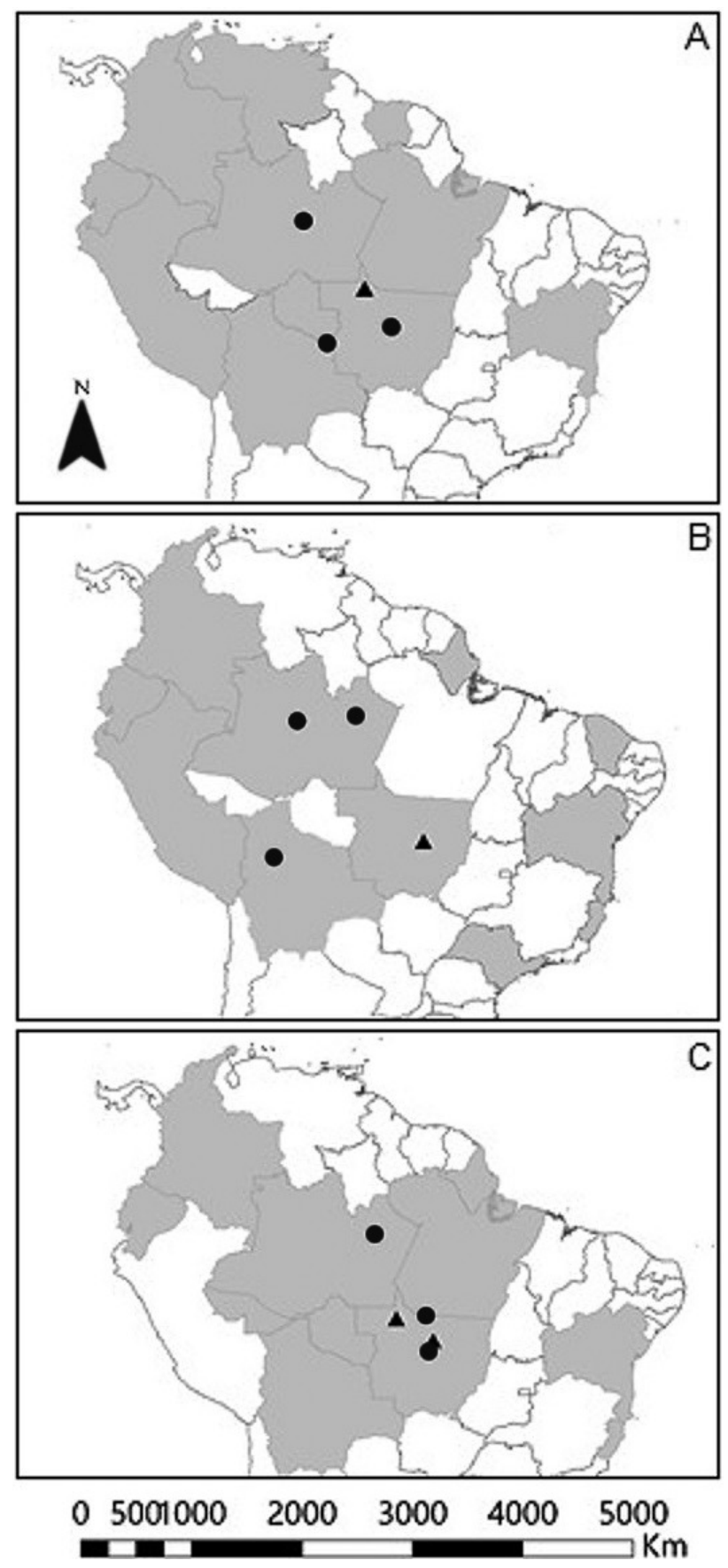

Figure 1. Distribution map of Camponotus apicalis (A), Camponotus chartifex (B) and Camponotus nidulans (C). Countries (and states within Brazil) in which the species has been recorded are highlighted in gray. Triangles represent our new records, and circles represent the closest previously known records to our collection sites. Previous records are from Kempf 1972; Adis et al. 1998; Fernández 2002 

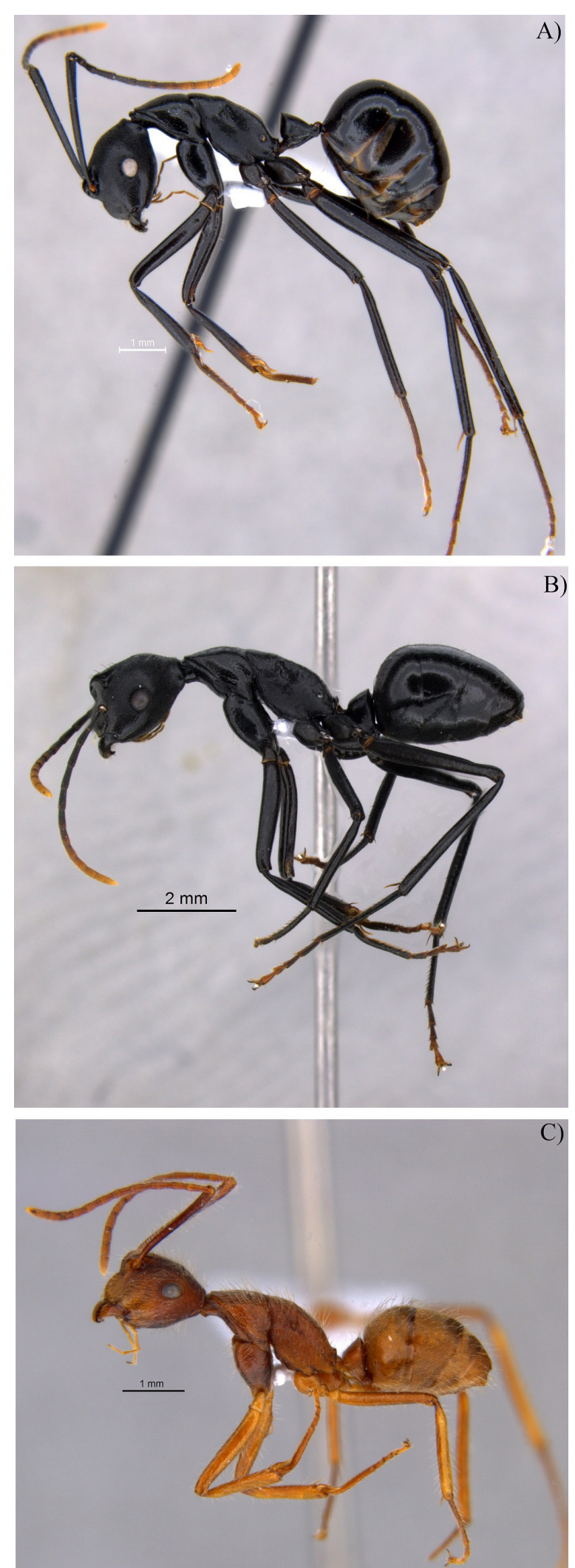

Figure 2. Images of Camponotus apicalis (A), Camponotus chartifex (B) and Camponotus nidulans (C) sampled in Mato Grosso, Brazil. This figure is in color in the electronic version. from Honduras to Bolivia (Fernández 2002; Fernández and Sendoya 2004). Previous records in Brazil are from the northern, northeastern and southeastern regions, in the states of Amapá, Amazonas, Pará, Bahia, Sergipe, Espírito Santo, and São Paulo (Fernández 2002). The nearest known occurence relative to our record in Mato Grosso is Ducke Reserve, in the municipality of Manaus, Amazonas state, Brazil (Harada and Adis 1998), more than $600 \mathrm{~km}$ in a straight line from our collection site.

Camponotus chartifex was found nesting at $81 \mathrm{~cm}$ from the ground in an unidentified palm tree. The nest was constructed mostly from silk-like material, made from organic matter rich in plant fibers. This nesting habit is known for the "weaver ants", that are abundant throughout the world, including the Neotropics (Santos et al. 2005). When the nest was found, at 12:07 h, the ants were inactive inside the nest (Figure 3A). When measuring the distance from the nest to the ground, the disturbance generated an evasive behavior. During this display, C. chartifex worker ants ran with immature individuals between their mandibles and with their gasters suspended, releasing formic acid that emitted an acetic odor (Figure 3B).
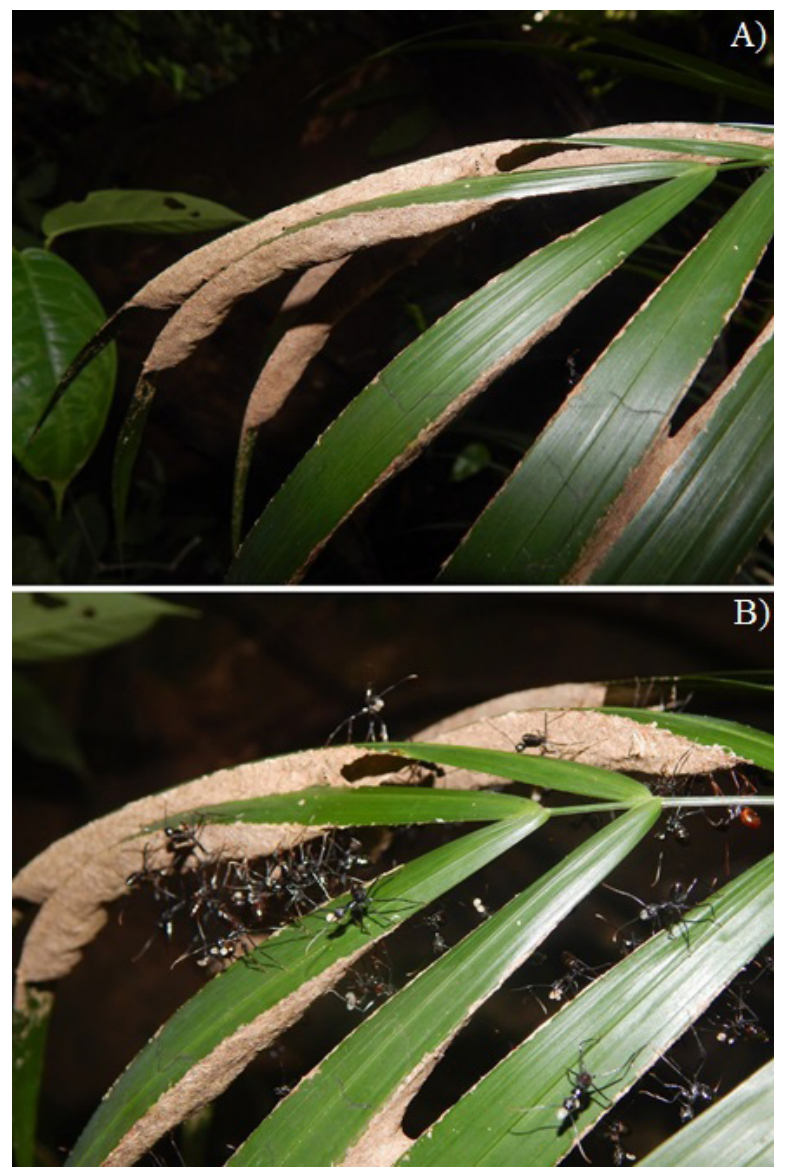

Figure 3. Images of a Camponotus chartifex nest without workers in activity (A) and showing worker activity (B) in Parque Nacional do Juruena, municipality of Apiacás, Mato Grosso state, Brazil. This figure is in color in the electronic version. 
We also observed that workers hit their gasters heavily against the nest surface, emitting a sound like a drum beat, which was occasionally triggered together. This behavior is known as "drumming" (Santos et al. 2005) and is very common in weaver ants, including in the Neotropical Camponotus (Fuchs 1976; Hölldobler and Wilson 1990; Vicente et al. 2014; Aguiar and Santos 2017). Drumming behavior may be displayed as an alarm response to stimuli or during recruitment (Santos et al. 2005; Aguiar and Santos 2017).

Camponotus nidulans is distributed from southeast Mexico to Bolivia (Kempf 1972; Jeanne 1979; Ryder-Wilkie et al. 2010). In Brazil, it occurs in the northern, northeastern and southeastern regions, in the states of Amapá, Amazonas, Pará, Acre, Rondônia, Mato Grosso, Bahia, and Espírito Santo (Kempf 1972; Fernández 2002). This new record of $C$. nidulans is located more than $400 \mathrm{~km}$ from its nearest previously known occurrence in Mato Grosso state (Fernández 2002).

Although $C$. apicalis and $C$. nidulans were not seen active in the daytime, workers of $C$. nidulans were sampled when active in the understory vegetation during the day in Claudia and Cotriguaçu. The species is known for intraspecific variation in color and degrees of pilosity. This morphological plasticity may reflect on the ability to forage during the day and the night, or only during the day, allowing the species to adapt locally to niche partitioning to avoid competition with sympatric species that have the same ecological requirements.

Few studies of arboreal ants have been conducted in the Neotropics, resulting in few records of arboreal ants in the literature (Kempf 1972; Fernández 2002; Vasconcelos et al. 2010; Vicente et al. 2016), since many species have a life history limited to the plants in which they live (Vicente et al. 2012; Prado et al. 2016). In addition to the little knowledge about the distribution of Neotropical ants (Santos-Silva et al. 2016; Vicente et al. 2016), still less is known about their reproductive biology, (Kaspari et al. 2001a, b; Boudinot 2015; Feitosa et al. 2016). Therefore, the use of sampling methods that capture winged ants should be encouraged in studies of ant diversity, despite the difficulty in identifying the species (Boudinot 2015). The challenge of associating winged individuals with workers results in data on winged ants being disregarded. All these complications are exacerbated in the case of arboreal ants, which often are not included in fauna surveys, resulting in a fragmented knowledge about species distribution. The beating-tray methodology, which is rarely used in ant surveys, can be a simple, inexpensive and efficient alternative method to improve ant samplings.

\section{ACKNOWLEDGMENTS}

We thank Livia Píres do Prado for reading the previous version of this manuscript, and Rodrigo Feitosa, from Universidade Federal do Paraná - UFPR for identification of the ants. REV acknowledges Museu Paraense Emílio Goeldi -MPEG and
Ministério da Ciência, Tecnologia, Inovações e Comunicações -MCTIC (PCI reserach fellowship \# 301081/2017-4) and Fundação de Amparo à Pesquisa do Estado de Mato Grosso - FAPEMAT and Conselho Nacional de Desenvolvimento Científico e Tecnológico - CNPq (edital nº03/2016) (DCR research fellowship). This work is publication 55 in the NEBAM technical series.

\section{REFERENCES}

Adis, J.; Harada, A.Y.; Fonseca, C.R.V.; Paarmann, W.; Rafael, J.A. 1998. Arthropods obtained from the Amazonian tree species "cupiuba" (Goupia glabra) by repeated canopy fogging with natural pyrethrum. Acta Amazonica, 28: 273-283.

Aguiar, J.J.M.; Santos, J.C. 2017. New Record of Dolichoderus quadridenticulatus (Roger, 1862) (Hymenoptera: Formicidae) from Amazonas, Brazil. Entomological News, 126: 400-404.

AntWeb, 2018. (https://www.antweb.org). Accessed on 08/05/2018.

AntMaps, 2018. (http://antmaps.org/?). Accessed on 08/05/2018.

Baccaro, F.B.; Feitosa, R.M.; Fernández, F.; Fernandes, I.O.; Izzo, T.J.; de Souza, J.L.P.; Solar, R.R.C. 2015. Guia para os gêneros de formigas do Brasil. Editora INPA, Manaus, 388p.

Boudinot, B.E. 2015. Contributions to the knowledge of Formicidae (Hymenoptera, Aculeata): a new diagnosis of the family, the first global male-based key to subfamilies, and a treatment of early branching lineages. European Journal of Taxonomy, 120: 1-62.

Dáttilo, W.; Rico-Gray, V.; Rodrigues, D.J.; Izzo, T.J. 2013. Soil and vegetation features determine the nested pattern of antplant networks in a tropical rainforest. Ecological Entomology, 38: 374-380.

Feitosa, R.M.; Silva, R.R.D.; Aguiar, A.P. 2016. Diurnal flight periodicity of a Neotropical ant assemblage (Hymenoptera, Formicidae) in the Atlantic Forest. Revista Brasileira de Entomologia, 60: 241-247.

Fernandes, E.F.; Castro, M.M.D.; Barbosa, B.C.; Prezoto, F. 2014. Variation in nesting behavior of the arboreal ant Camponotus sericeiventris (Hymenoptera: Formicidae). Florida Entomologist, 97: 1237-1239.

Fernández, F. 2002. Revisión de las hormigas Camponotus subgénero Dendromyrmex (Hymenoptera: Formicidae). Papéis Avulsos de Zoologia (São Paulo), 42: 47-101.

Fernández, F.; Sendoya, S. 2004. Lista de las hormigas neotropicales. Biota Colombiana, 5: 3-109.

Fuchs, S. 1976. The response to vibrations of the substrate and reactions to the specific drumming in colonies of carpenter ants (Camponotus, Formicidae, Hymenoptera). Behavioral Ecology and Sociobiology, 1: 155-184.

Guenard, B.; Weiser, M.D.; Gomez, K.; Narula, N.; Economo, E.P. 2017. The Global Ant Biodiversity Informatics (GABI) database: synthesizing data on the geographic distribution of ant species (Hymenoptera: Formicidae). Myrmecological News/Osterreichische Gesellschaft fur Entomofaunistik, 24: 83-89.

Harada, A.Y.; Adis, A. 1998. Ants obtained from trees of a "Jacareúba" (Calophyllum brasiliense) forest plantation in Central Amazonian by canopy fogging: first results. Acta Amazonica, 28: 309-318. 
Hölldobler, B.; Wilson, E.O. 1990. The ants. Harvard University Press, Berlin, 733p.

Jeanne, R.J. 1979. A latitudinal gradient in rates of ant predation. Ecology, 60: 1211-1224.

Kaspari, M.; Pickering, J.; Windsor, D. 2001a. The reproductive flight phenology of a neotropical ant assemblage. Ecological Entomology, 26: 245-257.

Kaspari, M.; Pickering, J.; Longino, J.T.; Windsor, D. $2001 \mathrm{~b}$. The phenology of a Neotropical ant assemblage: evidence for continuous and overlapping reproduction. Behavioral Ecology and Sociobiology, 50: 382-390.

Kempf, W.W. 1972. Catalago abreviado das formigas da regiao Neotropical (Hym. Formicidae). Studia Entomologica, 15: 3-344.

Prado, L.P.; Vicente, R.E.; Silva, T.S.R.; Souza, J.L.P. 2016. Strumigenys fairchildi Brown, 1961 (Formicidae, Myrmicinae): First record of this rarely collected ants from Brazil. Check List, 12: e19524.

Ryder-Wilkie, K.T.; Mertl, A.L.; Traniello, J.F.A. 2010. Species diversity and distribution patterns of the ants of Amazonian Ecuador. Plos One, 5: e13146.

Santos, J.C.; Korndörfer, A.P.; Del-Claro, K. 2005. Defensive behavior of the weaver ant Camponotus (Myrmobrachys) senex (Formicidae: Formicinae): drumming and mimicry. Sociobiology, 46: 279-288
Santos-Silva, L.; Vicente, R.E.; Feitosa, R.M. 2016. Ant species (Hymenoptera, Formicidae) of forest fragments and urban areas in a Meridional Amazonian landscape. Check List, 12: 1-7.

Suguituru, S.S.; Morini, M.S.C.; Feitosa, R.M.; Silva, R.R. 2015 Formigas do Alto Tietê. Canal 6 editora, Bauru, 456p.

Vasconcelos, H.L.; Vilhena, J.M.S.; Facure, K.G.; Albernaz, A.L.K.M. 2010. Patterns of ant species diversity and turnover across 2000 kilometres of Amazonian floodplain forest. Journal of Biogeography, 37: 432-440.

Vicente, R.E.; Dáttilo, W.; Izzo, T.J. 2012. New record of a very specialized interaction: Myrcidris epicharis Ward 1990 (Pseudomyrmecinae) and its myrmecophyte host Myrcia madida McVaugh (Myrtaceae) in Brazilian Meridional Amazon. Acta Amazonica, 42: 567-570.

Vicente, R.E.; Dáttilo, W.; Izzo, T.J. 2014. Differential recruitment of Camponotus femoratus (Fabricius) ants in response to ant garden herbivory. Neotropical Entomology, 43: 519-525.

Vicente, R.E.; Prado, L.P.; Izzo, T.J. 2016. Amazon Rainforest Ant-Fauna of Parque Estadual do Cristalino: Understory and Ground-Dwelling Ants. Sociobiology, 63: 894-908.

RECEIVED: $21 / 05 / 2018$

ACCEPTED: $13 / 09 / 2018$

ASSOCIATE EDITOR: Fabrício Baccaro 